\title{
Світлана САС
}

аспірантка кафредри фрінансів, грошового обігу і кредиту, Львівський національний університет імені Івана Франка, Львів, Україна, svitlana.sas@Inu.edu.ua ORCID ID: 0000-0001-9142-1959

\section{ФІНАНСУВАННЯ ВИЩОї ОСВІТИ УКРАЇНИ: СТАН, ТЕНДЕНЦIї РОЗВИТКУ ТА ПЕРСПЕКТИВИ}

Вступ. В умовах розвитку економіки знань та безперервного рефрормування системи вищої освіти (CВО) України їі ефективне фрінансове забезпечення відповідає найважливішим потребам сучасності та сприяє фрормуванню інтелектуального потенціалу держави, соціально-економічному розвитку суспільства й зростанню національної економіки на засадах інноваційно-технологічного прогресу.

Мета - провести аналіз сучасного стану вищої освіти, їі фрінансового забезпечення та визначити перспективи розвитку цієї пріоритетної галузі економіки.

Meтоди. У процесі дослідження використано аналіз і синтез, методи порівняння й узагальнення, а також прогнозування, моделювання та ін.

Результати. У статті приділена увага питанням розвитку вищої освіти України, яка перебуває в перманентному стані реформування та інтеграції у світовий освітньо-науковий простір. Проаналізовано сучасний стан вищої освіти держави та їі фрінансування на світовому й національному рівнях. З'ясовано, що витрати на вищу освіту зазнають постійних коливань, на що впливають, зокрема, зовнішні політичні та економічні фрактори.

За результатами проведеного наукового дослідження зроблено висновки, що роль держави у фрінансуванні вищої освіти щорічно зростає, проте актуальним залишається залучення альтернативних джерел - участь в освітніх, наукових, інфрраструктурних проєктах, співпраця з бізнесом, виробництвом, випускниками, надання платних послуг, що фрормує перспективи розвитку освіти й науки - пріоритетної галузі економіки країни.

Ключові слова: вища освіта, заклади вищої освіти, система вищої освіти, тенденції, фрінансування, стратегія фрінансового забезпечення.

Рис.: 2, табл.: 4, форм.: 4, бібл.: 15.

\section{Светлана СAC}

аспирантка кафредры фринансов, денежного обращения и кредита, Львовский национальный университет имени Ивана Франко, Львов, Украина

\section{ФИНАНСИРОВАНИЕ ВЫСШЕГО ОБРАЗОВАНИЯ УКРАИНЫ: СОСТОЯ- НИЕ, ТЕНДЕНЦИИ РАЗВИТИЯ И ПЕРСПЕКТИВЫ}

Введение. В условиях развития экономики знаний и непрерывного реформирования системы высшего образования (СВО) Украины, её эфффективное фринансовое обе(c) Світлана Петрівна Сас, 2021 
спечение отвечает важнейшим потребностям современности и способствует фрормированию интеллектуального потенциала государства, социально-экономическому развитию общества и национальной экономики, базирующихся на инновационно-технологическом прогрессе.

Цель - проанализировать современное состояние высшего образования, его фринансовое обеспечение и определить перспективы развития этой приоритетной отрасли экономики.

Методы. В процессе исследования использованы анализ и синтез, сравнение и обобщение, а также методы прогнозирования и моделирования.

Результаты. В статье уделено внимание вопросам развития высшего образования Украины, находящегося в перманентном состоянии реформирования и интеграции в мировое образовательно-научное пространство. Проанализировано современное состояние высшего образования государства и его финансирования на мировом и национальном уровнях. Установлено, что расходы на высшее образование подвергаются постоянным колебаниям, на что влияют, в частности, внешние политические и экономические фракторы.

По результатам проведенного научного исследования сделаны выводы о том, что роль государства в финансировании высшего образования ежегодно растет, однако актуальным остается привлечение альтернативных источников - участие в образовательных, научных, инфраструктурных проектах, сотрудничество с бизнесом, производством, выпускниками, предоставление платных услуг, что формирует перспективы развития образования и науки - приоритетной отрасли экономики страны.

Ключевые слова: высшее образование, высшие учебные заведения, система высшего образования, тенденции, финансирование, стратегия финансового обеспечения.

\section{Svitlana SAS}

Graduate student, Ivan Franko National University of Lviv, Ukraine, svitlana.sas@Inu.edu.ua ORCID ID: 0000-0001-9142-1959

\section{FINANCING OF HIGHER EDUCATION OF UKRAINE: STATE, DEVELOP- MENT TRENDS AND PROSPECTS}

Introduction. In the conditions of knowledge economy development, continuous reforming of the system of higher education of Ukraine, its effective financial provision meets the most important needs of modernity and promotes formation of intellectual potential of the state, social and economic development of society and growth of national economy.

The purpose of the article is to analyze the current state of higher education, its financial support and determine the prospects for the development of this priority sector of the economy.

Methods. During the research the analysis and synthesis, comparison, generalization, forecasts, trends, modeling and other methods were used.

Results. The current state of higher education of the state and its financing at the world and national levels is analyzed. Expenditures on higher education have been found to fluctuate constantly, due in particular to external political and economic factors. According to the results of the research, it is concluded that the role of the state in financing higher education is growing every year, but the involvement of alternative sources such as participation in educational, 
scientific, infrastructure projects, cooperation with business, industry, graduates, and providing paid services remains relevant.

Keywords: higher education, institutions of higher education, system of higher education, tendencies, financing, strategy of financial provision.

JEL Classification: H52, I22, 128.

Постановка проблеми. Освіта і наука $€$ вагомими чинниками економічного зростання кожної країни, соціального розвитку суспільства, а капіталовкладення держави у цю галузь економіки - іï̈ першочерговим завданням. Належне фінансування розвитку ссрери вищої освіти України в умовах ії інтеграції у світовий освітньо-науковий простір залишається актуальним питанням сьогодення. Бюджетне та небюджетне фрінансове забезпечення, залучення альтернативних джерел фрінансування системи вищої освіти (CBO) та динаміка змін й реформ, що відбуваються, - фрактори, які мають беззаперечний вплив на українську вищу освіту.

Аналіз останніх досліджень і публікацій. Однією із пріоритетних галузей економіки кожної країни є освіта і наука, тому актуальність ії̈ дослідження присутня як серед іноземних, так і українських науковців. Значний внесок у дослідження питань розвитку та фрінансування освіти зробили такі відомі зарубіжні вчені, як: Дж. Брей, Р. Гуде [1], Б. Кларк, Дж. Салмі, Дж. Субоцькі, Т. Шульц [2], а також сучасні дослідники А. Падловська [3], М. Нкісі [4], П. Петров [5], М. Камерова-Тімерова [5], Г. Віка Оларіу [6], С. Бред [6], М. Фулеа [6], С. Мухамед [7], Н.Ф. Чі Сулейман [7], Дж. Сапутра [7]. Проблемам фрінансування вищої освіти та науки, питанням фрінансового забезпечення навчальних закладів присвячені наукові праці багатьох вітчизняних дослідників, а саме: В. Андрущенка, Д. Біленко, Т. Боголіб, О. Буцької, 3. Варналія, О. Гринькевич, О. Кириленко, О. Красільнік, М. Крупки,
С. Левицької, І. Лютого, В. Малишко, В. Опаріна, Т. Філатової, І. Чугунова, Л. Шевченко, Т. Ящук та ін.

Мета статті передбачає аналіз сучасного стану вищої освіти, ії̈ фрінансового забезпечення та визначення перспективи розвитку цієї пріоритетної галузі економіки.

Виклад основного матеріалу дослідження. Як вважають вчені різних країн світу, освіта $€$ однією із найважливіших складових людського капіталу й стійким фактором економічного зростання [1; 2; 3]. Підтверджують це й сучасні науковці, аргументуючи, що вища освіта відіграє провідну роль у досягненні країнами їхнього соціально-економічного розвитку та у створенні конкурентоспроможної, кваліфрікованої робочої сили в усьому світі, а потреба в ній у поєднанні з дефіцитом фрінансових ресурсів зумовила той факт, що уряди вирішили фрінансувати вищу освіту [4]. Саме вона $€$ головним фрактором конкурентоспроможності країн й підвищує конкуренцію та інновації на внутрішніх ринках [5]. Водночас державні заклади вищої освіти вже давно розглядають як організації, які мають значний вплив на економічний розвиток та прогрес цивілізації [6]. Дослідивши роль людського капіталу та інноваційного потенціалу в економічному зростанні азійських країн, вчені дійшли висновку, що як людський капітал, так і інноваційний потенціал $€$ життєво важливими для стимулювання економічного зростання і забезпечується навчанням у закладах вищої освіти й державними витратами на освіту [7]. 
Використовуючи Рейтинг національних систем вищої освіти (U21 Rankings of National Higher Education Systems) [8], що вимірює досягнення країн світу у сфері вищої освіти за версією міжнародної мережі університетів Universitas 21, проаналізуємо стан вищої освіти України у світовому вимірі. Зазначений вище рейтинг передбачає дослідження п'ятдесяти національних СВО з усіх континентів за 24 показниками, які формують чотири групи - ресурси (20\%), середовище (20\%), зв'язок (20\%), результат, продуктивність (40\%). Цей рейтинг комплексно визначає критерії оцінки СВО та тенденції її розвитку в умовах сьогодення.

Ресурси, зокрема, враховують такі показники, як загальні витрати на ЗВО, в тому числі і його державні витрати, річні витрати на одного студента (еквівалент денної фрорми) в паритеті купівельної спроможності в доларах США, витрати в ЗВО на НДДКР як відсоток від ВВП, видатки на ЗВО на НДДКР на одну особу населення за купівельною спроможністю в доларах США. Друга група - середовище, що є важливим визначальним фактором результатів, оскільки оцінює сферу, оточення, в якому працюють ЗВО - політика уряду щодо забезпечення рівня фрінансової та академічної самостійності 3ВО, сприяння різноманітності та конкуренції між ними, можливість здобути якісну вищу освіту, гендерна політика та інше. Щодо третьої групи показників - зв'язок, то вони відображають рівень міжнародної співпраці та відкритості чи замкнутості СВО країни. Це і питома вага іноземних студентів на вищому рівні освіти, частка статей у співавторстві $з$ міжнародними співробітниками, кількість зовнішніх посилань, які отримують вебдомени університету, розділені на населення країни.

Найвагомішою групою показників $€$ результат, що оцінює пропускну здатність студентів, національний запас випускників та дослідників, якість кращого університету та працевлаштування випускників, продуктивність досліджень, проведених дослідниками ЗВО країни.

Аналізуючи щорічні результати зазначеного вище рейтингу, очевидно, що Україна прагне зайняти середні позиції серед інших країн світу (2012 рік - 25 місце, 2013 - 25, 2014 - 42, 2015 - 41, 2016 - 42, 2017 - 35, 2018 - 38, 2019 - 38, 2020 - 36). В загальному рейтингу наша держава поступається місцем економічно розвиненим країнам світу, зокрема, таким країнам, як: США, Швейцарія, Великобританія, Канада, Австралія, Австрія, Японія, Китай. Проте важливо зазначити, що Україна має значний потенціал для нарощування своєї конкурентоспроможності. Розглянувши оцінки за показниками, що фрормують місце в рейтингу у 2020 р., можна констатувати, що ресурси складають 52,6\%, порівняно з іншими країнами, і Україна за цим показником посідає 27 місце, витісняючи такі країни, як: Іспанія, Польща, Китай, Італія та ін. Водночас за іншими групами показників: середовище 70,6\% (39 місце), зв'язок - 40,4\% (38 місце), результат, продуктивність - 28,7\% (42 місце). Отож, щоб займати кращі місця у рейтингу, в подальшому важливо звернути увагу на показники, які включені у нього, й у інші міжнародні та національні рейтинги і поступово підвищувати їхній рівень.

У контексті дослідження розглянемо основні фрінансові показники функціонування СВО України. За результатами аналізу статистичних даних можна зазначити, що загальні витрати на вищу освіту у гривнях щорічно зростають. Так, упродовж 2007-2019 рр. вони збільшились на 49929,2 млн грн (2007 рік - 23166,6 млн грн, 2019 р. - 73095,8 млн грн), проте у \% до ВВП країни знижуються впродовж цих років (2007 р. - 3,2\%, 2019 р. - 1,8\%). Обсяг бюджетних витрат на вищу освіту у ВВП 
країни у зазначений період також скоротився. Якщо у 2007 р. вони складали 13395,9 млн грн і 1,9\% від ВВП країни, то у 2019 - 53495,4 млн грн (1,3\%). Найбільші державні витрати на вищу освіту в цей період були у 2009 та 2010 рр. і становили 2,4\% до обсягу ВВП країни.

В перерахунку в доларовий еквівалент витрати на вищу освіту зазнають постійних коливань, на що впливає нестабільність гривні, спричинена зовнішніми політичними та економічними факторами. Як свідчать дані рис. 1, стрімке падіння витрат на вищу освіту у дол. США, зокрема, й за рахунок державного сектору, спостерігалося з 2014 р. і тривало наступні три роки. I лише у 2017, 2018, 2019 рр. почалося незначне зростання цих видатків. Зниження витрат на вищу освіту у дол. США загалом й за рахунок бюджету зокрема у 2014 р., порівняно із 2013 р., становило $37 \%$, а порівняно з 2018 р. - 57\%. Щодо 2019 р., то загальні витрати на вищу освіту у дол. США зменшилися на $50 \%$, а витрати державного сектору - на $47 \%$.

Проведемо дослідження економічних процесів в українській галузі освіти, загаль- них особливостей й тенденцій її розвитку за допомогою побудови прогнозів з урахуванням закономірностей, які сформувалися в попередніх періодах. Для дослідження тенденцій, які мають місце у сфері фрінансування вищої освіти, вважаємо за доцільне побудувати математичні моделі для наближення та прогнозування зміни деяких важливих показників, які характеризують стан цієї сфрери. Моделювання проведемо за допомогою математичного апарату часових трендів.

Часовим трендом називається залежність:

$$
y=f(t)+\varepsilon_{t}
$$

де $f(t)$ - детермінована (невипадкова) компонента процесу (явища);

$\varepsilon_{t}$ - стохастична (випадкова) компонента процесу.

Тренд відображає тенденцію зміни процесу (явища) в часі. Припускається, що через фактор часу $t$ можна виразити вплив усіх основних факторів. Реальний механізм впливу на значення рівнів динамічних рядів у даному випадку не враховується.

Витрати на вищу освіту, млн дол. США

В Витрати державного сектору на вищу освіту, млн дол. США

—юджетні витрати на вищу освіту у \% до ВВП країни

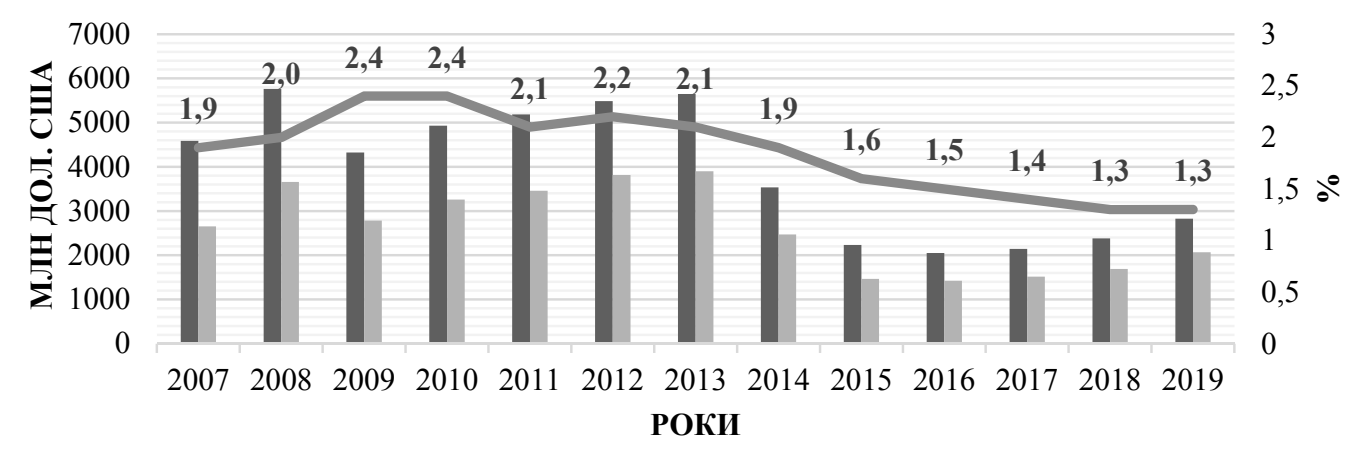

Рис. 1. Динаміка основних показників фрінансування вищої освіти України* * Побудовано на основі [9]. 
У дослідженні використаємо такі типи залежностей, що описують рівняння тренду $[10 ; 11]$ :

- лінійна $y=a_{0}+a_{1} t$;

- кубічна $y=a_{0}+a_{1} t+a_{2} t^{2}+a_{3} t^{3}$,

де $a_{0}, a_{1}, a_{2}, a_{3}$ - невідомі параметри, які потрібно оцінити.

Невідомі коефіцієнти цих моделей обчислимо за допомогою методу найменших квадратів з використанням пакету Excel.

Для перевірки якості (адекватності) побудованих моделей використаємо коефіцієнт детермінації:

$$
R^{2}=\frac{\sum_{t=1}^{n}\left(\tilde{y}_{t}-\bar{y}\right)^{2}}{\sum_{t=1}^{n}\left(y_{t}-\bar{y}\right)^{2}},
$$

де $\tilde{y}_{t}-$ теоретичні значення залежної змінної, $\bar{y}$ - середнє значення змінної $y$. Чим більше значення цього коефіцієнта наближається до 1, тим краще побудована модель відображає процес.

Розрахунок прогнозних значень здійснимо шляхом підстановки у рівняння трен- ду значення незалежної змінної $t$, що відповідає величині горизонту прогнозування, тобто:

$$
\tilde{y}_{t+p}=f\left(t_{n+p}\right),
$$

де $p$ - величина горизонту прогнозування (періоди, на які складають прогноз).

Отож дані аналізу (табл. 1), враховуючи закономірності, які склалися в попередніх періодах, свідчать про подальше зниження витрат на вищу освіту в еквіваленті до дол. США, проте будемо сподіватися на стабілізацію ситуації в державі та, відповідно, зміну прогнозів.

Порівнюючи витрати у 2016 р. на вищу освіту 3 державних джерел в дол. США та у відсотках до ВВП в окремих країнах світу і Центральної та Східної Європи, а також державне фрінансування на одного студента, що здобуває вищу освіту, в дол. США (табл. 2), можна спостерігати суттєвий дисбаланс. Найбільш показово відображає рівень фрінансування СВО, розрахунок фрінансування на одного студента ЗВО. Цей показник вказує на результативність вищої

Таблиця 1

\begin{tabular}{|c|c|c|c|c|c|c|c|}
\hline \multicolumn{8}{|c|}{ Лінійне рівняння тренда $\widetilde{y}=5955,7-289,42 t$} \\
\hline \multicolumn{8}{|c|}{ Коефіцієнт детермінації $R^{2}=0,6034$} \\
\hline \multicolumn{8}{|c|}{ y - витрати на вищу освіту за період з 2007 по 2019 рр., млн дол. США } \\
\hline Роки & $\begin{array}{c}\text { Номер } \\
\text { періоду } t\end{array}$ & $\begin{array}{c}\text { Реальне } \\
\text { значення } y\end{array}$ & $\begin{array}{l}\text { Теоретичне } \\
\text { значення } \widetilde{y}\end{array}$ & Роки & $\begin{array}{l}\text { Номер } \\
\text { періоду } t\end{array}$ & $\begin{array}{c}\text { Реальне } \\
\text { значення } y\end{array}$ & $\begin{array}{l}\text { Теоретичне } \\
\text { значення } \widetilde{y}\end{array}$ \\
\hline 2007 & 1 & 4587,4 & 5666,28 & 2015 & 9 & 2233 & 3350,92 \\
\hline 2008 & 2 & 5760,1 & 5376,86 & 2016 & 10 & 2048,7 & 3061,5 \\
\hline 2009 & 3 & 4322,5 & 5087,44 & 2017 & 11 & 2143,2 & 2772,08 \\
\hline 2010 & 4 & 4931 & 4798,02 & 2018 & 12 & 2381,9 & 2482,66 \\
\hline 2011 & 5 & 5186,4 & 4508,6 & 2019 & 13 & 2827,7 & 2193,24 \\
\hline 2012 & 6 & 5487 & 4219,18 & 2020 & 14 & & 1903,82 \\
\hline 2013 & 7 & 5645,6 & 3929,76 & 2021 & 15 & & 1614,4 \\
\hline 2014 & 8 & 3533,3 & 3640,34 & 2022 & 16 & & 1324,98 \\
\hline
\end{tabular}

\section{पасовий тренд для аналізу витрат на вищу освіту*}

* Складено на основі [9]. 
Показники рівня фінансування СВО окремих країн світу у 2016 р.*

\begin{tabular}{|c|c|c|c|}
\hline Країни & $\begin{array}{c}\text { Державні витрати } \\
\text { на вищу освіту, млн } \\
\text { дол. США }\end{array}$ & $\begin{array}{c}\text { Частка державних } \\
\text { витрат на вищу } \\
\text { освіту у ВВП, \% }\end{array}$ & $\begin{array}{c}\text { Державне фінансу-вання } \\
\text { на } 1 \text { студента, що здобуває } \\
\text { вищу освіту, дол. США }\end{array}$ \\
\hline Україна & 1424,53 & 1,53 & 843,06 \\
\hline \multicolumn{4}{|c|}{ Країни світу } \\
\hline Австралія & 17110,93 & 1,41 & 8918,33 \\
\hline Аргентина & 6297,22 & 1,13 & 2057,15 \\
\hline Велика Британія & 40710,24 & 1,41 & 16895,18 \\
\hline Канада & 25127,79 & 1,62 & 13674,88 \\
\hline Китай & 3100,70 & 1,00 & 10324,79 \\
\hline Малі & 94,32 & 0,67 & 1457,46 \\
\hline Російська Федерація & 10374,92 & 0,81 & 1733,43 \\
\hline США & 220602,74 & 1,21 & 11036,65 \\
\hline Японія & 27688,32 & 0,63 & 7115,16 \\
\hline \multicolumn{4}{|c|}{ Країни Центральної і Східної Європи } \\
\hline Естонія & 336,47 & 1,40 & 6547,50 \\
\hline Литва & 353,49 & 0,82 & 2510,47 \\
\hline Німеччина & 43604,21 & 1,25 & 14253,06 \\
\hline Польща & 5002,32 & 1,06 & 3104,52 \\
\hline Румунія & 1333,03 & 0,71 & 2496,54 \\
\hline Сербія & 427,55 & 1,05 & 1702,27 \\
\hline Словаччина & 746,74 & 0,83 & 4281,56 \\
\hline Словенія & 423,24 & 0,95 & 5226,68 \\
\hline Угорщина & 954,45 & 0,76 & 3262,39 \\
\hline Чехія & 1373,02 & 0,70 & 3755,64 \\
\hline
\end{tabular}

* Складено на основі [12].

освіти в країні. І, на жаль, серед 20 досліджуваних країн світу цей показник в Україні найнижчий, коли частка державних витрат на вищу освіту у ВВП є однією з найвищих (вища лише в Канаді).

Динаміку змін підходів щодо фрінансування, їхню вагу у розподілі витрат на вищу освіту між фрінансуючими організаціями (державним та недержавним секторами) у 2007-2019 рр. відображено на рис. 2, де спостерігаємо врівноважену тенденцію до збільшення ваги державного сектору у фрінансуванні вищої освіти.
Аналізуючи дані рис. 2, можна зауважити, що у 2007 р. відсоток витрат на вищу освіту, що здійснювалися за рахунок державного сектору, становив 57,8 й поступово підвищувався. У 2010 р. він уже становив $66,1 \%$, а у $2019-73,2 \%$. Це ще раз підтверджує роль держави у формуванні якісної освіти та конкурентоспроможної української науки.

Недержавне фрінансове забезпечення вищої освіти у 2007-2019 рр. фрормувалося за рахунок приватних фрірм та корпорацій (близько $2 \%$ усього забезпечення) й до- 


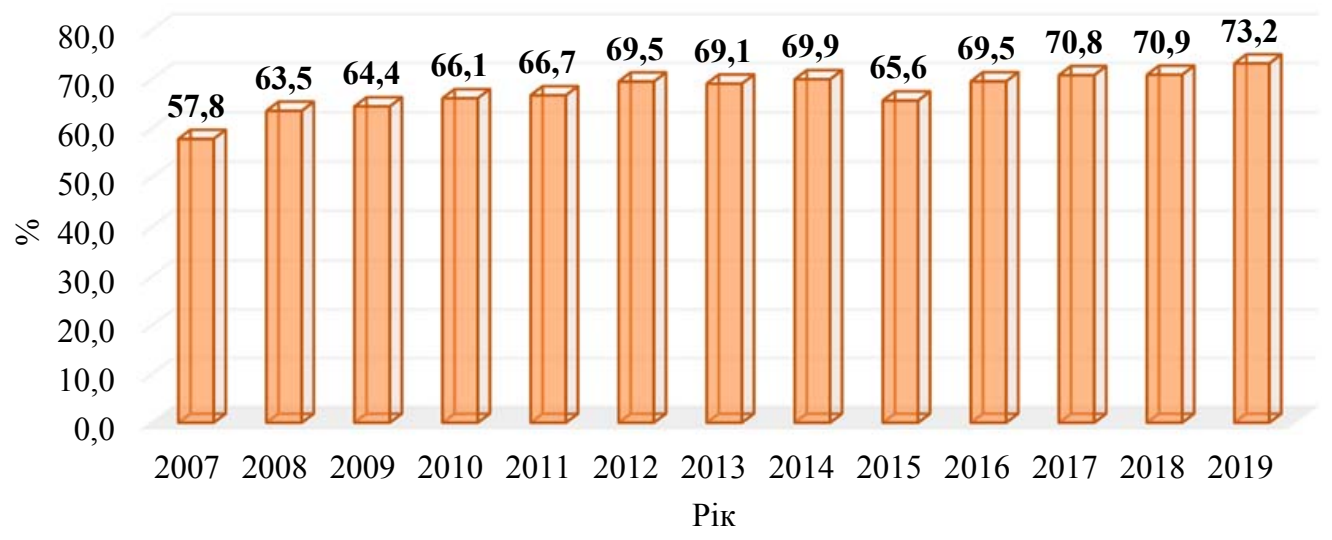

* Побудовано на основі [9].

Рис. 2. Динаміка фінансування вищої освіти України за рахунок державного сектору у 2007-2019 рр.*

машніх господарств (40-25\%). Залучення додаткових джерел фрінансування, вважаємо, перспективним для СВО України. Ними можуть бути: створення ендавмент-фондів, наукових та/або технологічних парків, стартапів, надання платних освітніх, наукових та інших послуг, участь у різних проєктах, ґрантах, співпраця з бізнесом, виробництвом, випускниками, пошук благодійників, котрі зацікавлені в розвитку освіти і науки.

Сучасну систему вищої освіти України формують університети, інститути, академії, заклади фахової передвищої освіти (коледжі), серед яких спостерігається тенденція до об'єднання та оптимізації. Дані табл. 3 демонструють динаміку зміни кількості ЗВО та прогноз наступних років.

Так, однією з цілей Стратегії розвитку вищої освіти України на 2021-2031 рр. є збалансування мережі 3ВО з урахуванням галузевих і регіональних пріоритетів та історичного надбання [14]. Як зазначив у своєму інтерв'ю міністр освіти і науки України С. Шкарлет, “Об'єднання ЗВО - це об'єктивний процес розвитку. Україна дуже велика країна, з неоднорідною щільністю населення. $€$ регіони, в яких значно менша кількість випускників шкіл, тому набір у де- які заклади вищої освіти зменшується, що зумовлює скорочення кількості студентів й викладачів, а відповідно, зменшення фінансування, що підштовхує до об'єднання закладів. У будь-якому випадку держава не зможе фрінансувати ту кількість закладів вищої освіти, але і ламати їх не можна. Це комплексний рух" [15].

Не менш, впливовими факторами зменшення кількості 3ВО є демографічна ситуація в країні та розширення можливостей студентської молоді здобувати освіту за кордоном.

Розрахувавши теоретичні значення зміни кількості ЗВО й студентів за допомогою часових трендів, спостерігаємо поступове їх зменшення, що $є$ неминучим явищем в Україні, а також стабільне зниження фактичної кількості студентів, які в них навчаються, та подальший прогноз їх динаміки (табл. 4). Ґрунтуючись на аналізі статистичних показників, прогнозних даних, вважаємо, що оптимізація мережі закладів вищої освіти, їх укрупнення, сприятимуть ефективному фрінансовому забезпеченню діючої системи, посиленню підтримки сфери вищої освіти загалом та підвищенню рівня витрат на одного сту- 
Часовий тренд для аналізу динаміки кількості ЗВО

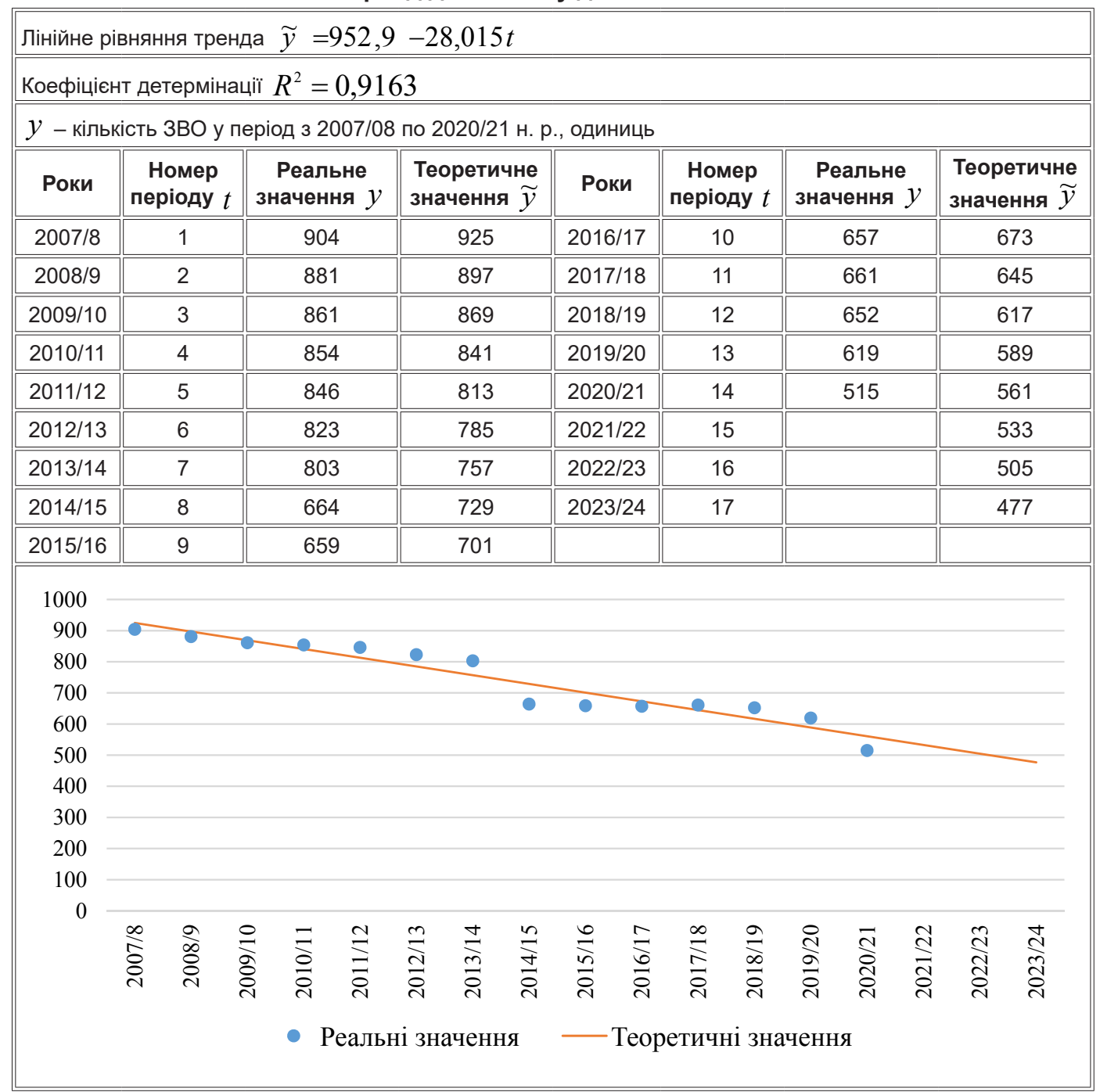

* Складено на основі [13].

дента, що, беззаперечно, $€$ показником ефективності соціально-економічного розвитку країни.

Висновки. Пріоритетність освітньонаукової сфрери у державній політиці України характеризується прагненням уряду забезпечити їі належним рівнем фінансування і підвищити ефективність функціонування в умовах глобалізаційних та євроінтеграційних процесів. Розглянувши сучасний стан розвитку та фрінансового забезпечення вищої освіти України, встановлено беззаперечну участь держави у цьому процесі (відсоток витрат на вищу освіту за рахунок державного сектору останніми роками сягає понад 70\%). Разом з тим значний вплив мають зовнішні політико-економічні фактори, які погір- 
Часовий тренд для аналізу динаміки кількості студентів у 3ВО*

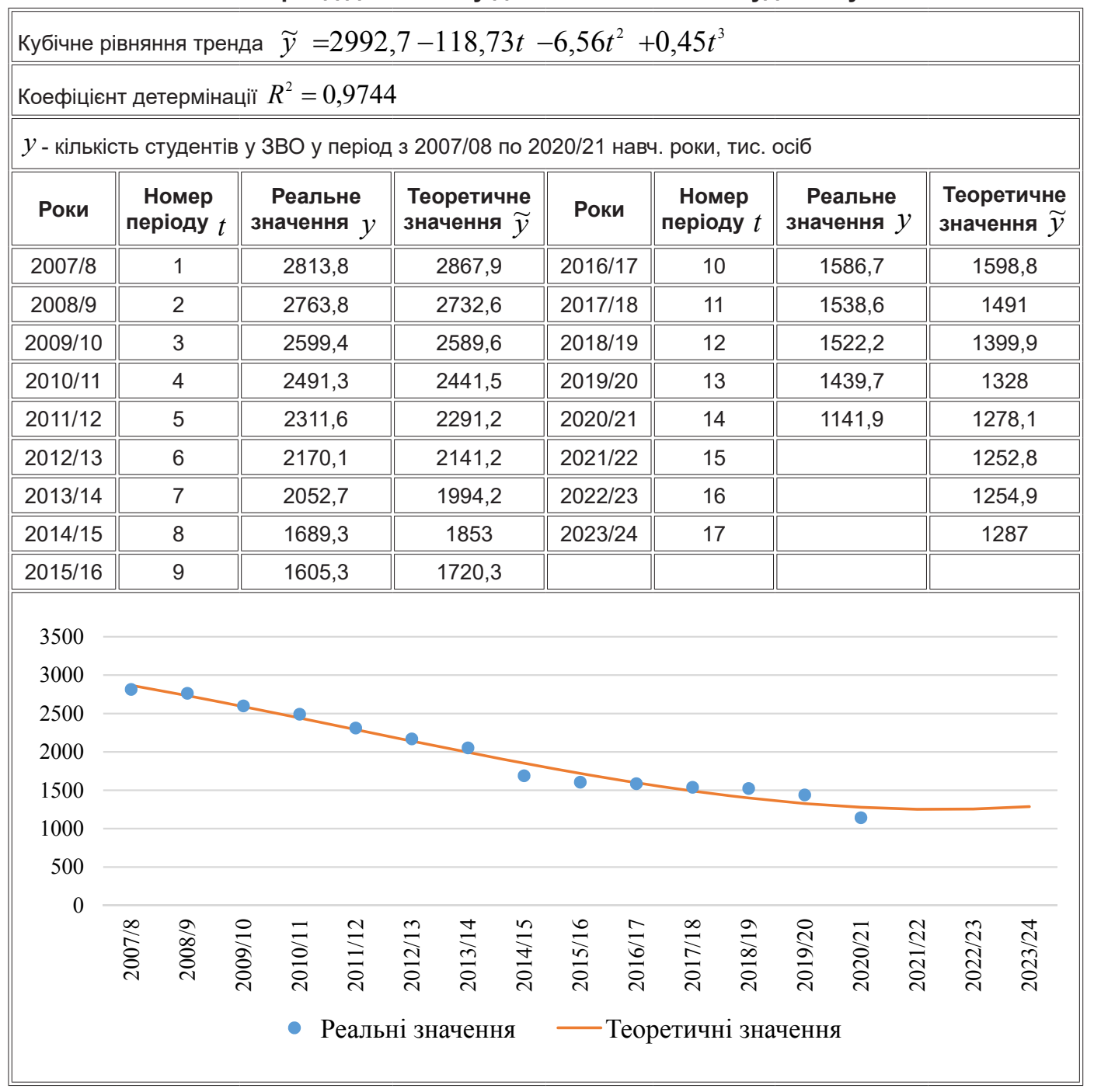

* Складено на основі [13].

шують показники ефективності, зокрема - витрати на підготовку одного студента. Водночас, вважаємо, що тенденція до оптимізації системи вищої освіти цілком аргументована і дасть змогу розширити фінансові можливості ЗВО, що сприятиме підвищенню якості освітніх послуг, рівня наукових досліджень і забезпечить економічне зростання й соціальний прогрес усіх учасників освітньо-наукового процесу. Не менш важливою перспективою розвитку вищої освіти є диверсифікація джерел фрінансування за допомогою залучення недержавних фрінансових ресурсів - участь у проєктах, ґрантах, співпраця 3 бізнесом, випускниками, меценатами. 


\section{Список використаних джерел}

1. Goode R. B. Adding to the stock of physical and human capital. The American Economic Review. 1959. № 49(2). P. 147-155.

2. Schultz T. W. Investment in human capital. New York: The Free Press, 1971.

3. Padlowska A. The strategy of the development of the higher education in Poland on the Warsaw university of technology example. Polish Journal of Management Studies. Wydział Zarządzania. 2014. Vol. 9. P. 205-216.

4. Nkisi M. Higher education financing in lesotho: regulation to realize its sustainability and increase inclusiveness. Journal of African Law. 2021. Vol. 65, Iss. 1. P. 25-45.

5. Petrov P., Kamenova-Timareva M. A key performance indicators a frameworkfor higher education institutions. Vanguard Scientific Instruments in Management. 2014. URL : https://www. academia.edu/43767142/A_Key Performance Indicators a Framework for Higher Education Institutions?email work card=view-paper.

6. Vica Olariu G., Brad S., Fulea M. The sustainable university in the new economic context. FAIMA Business \& Management Journal. 2020. Vol. 8. № 1. P. 5-18.

7. Muhamad S., Che Sulaiman N.F. \& Saputra J. The role of human capital and innovation capacity on economic growth in ASEAN-3. Jurnal Ekonomi Malaysia. 2018. № 52 (1). P. 281-295.

8. U21 Ranking of national higher education systems. URL : https://universitas21.com/rankings.

9. Державна служба статистики України. 2018. URL : www.ukrstat.gov.ua.

10. Грабовецький Б. Є. Економічне прогнозування і планування : навч. посіб. Київ : Центр навчальної літератури, 2003. 188 c.

11. Добуляк Л. П., Костенко С. Б. Використання трендових моделей для дослідження тенденцій розвитку малого підприємництва в Україні. Науковий вісник Ужгородського національного університету. Міжнародні економічні відносини та світове господарство. Вип. 24. 4. 1. 2019. C. 147-152.
12. The UNESCO Institute for statistics. URL : http://data.uis. unesco.org/?queryid=181\#.

13. Основні показники діяльності ЗВО в Україні на початок 2010/11-2019/20 навчальних років: стат. інформація. Київ : Держстат України. URL : http://www.ukrstat.gov.ua.

14. Стратегія розвитку вищої освіти України на 2021-2031. URL : https://mon.gov. ua/storage/app/media/rizne/2020/09/25/rozvitkuvishchoi-osviti-v-ukraini-02-10-2020.pdf.

15. Шкарлет С. Вища освіта в Україні. URL : https://osvita.ua/vnz/80198/.

\section{References}

1. Goode, R. B. (1959). Adding to the stock of physical and human capital. The American Economic Review, 49(2), 147-155.

2. Schultz, T. W. (1971). Investment in human capital. New York: The Free Press.

3. Padlowska, A. (2014). The strategy of the development of the higher education in Poland on the Warsaw university of technology example. Polish Journal of Management Studies. Wydział Zarządzania, 9, 205-216.

4. Nkisi, M. (2021). Higher education financing in lesotho: regulation to realize its sustainability and increase inclusiveness. Journal of African Law, 1, 25-45. (Vol. 65).

5. Petrov, P., Kamenova-Timareva, M. (2014). A key performance indicators a frameworkfor higher education institutions. Vanguard Scientific Instruments in Management. Available at: https:// www.academia.edu/43767142/A_Key_Performance Indicators a Framework for Higher Education Institutions?email work card=view-paper.

6. Vica Olariu, G., Brad, S., Fulea, M. (2020). The sustainable university in the ew economic context. FAIMA Business \& Management Journal, 1, 5-18. (Vol. 8).

7. Muhamad, S., Che Sulaiman, N.F. \& Saputra, J. (2018). The role of human capital and innovation capacity on economic growth in ASEAN-3. Jurnal Ekonomi Malaysia, 52 (1), 281-295. 


\section{ДЕРЖАВНІ ФІНАНСИ}

8. U21 Ranking of national higher education systems. Available at: https://universitas21.com/ rankings.

9. Derzhavna sluzhba statystyky Ukrainy. [State Statistics Service of Ukraine]. (2018). Available at: www.ukrstat.gov.ua.

10. Hrabovetskyi, B. Ye. (2003). Ekonomichne prohnozuvannia i planuvannia [Economic forecasting and planning] Kyiv: Tsentr navchalnoi literatury [in Ukrainian].

11. Dobuliak, L. P., Kostenko, S. B. (2019). Vykorystannia trendovykh modelei dlia doslidzhennia tendentsii rozvytku maloho pidpryiemnytstva $v$ Ukraini [Using trend models for analisys of small business development tendencies in Ukraine]. Naukovyi visnyk Uzhhorodskoho natsionalnoho universytetu. Seriia Mizhnarodni ekonomichni vidnosyny ta svitove hospodarstvo - Scientific Bulletin of Uzhhorod National University. International Economic Relations and the World Economy, 24, 147-152. (Part 1). [in Ukrainian].
12. The UNESCO Institute for statistics. Available at: http://data.uis. unesco.org/?queryid=181\#.

13. Osnovni pokaznyky diialnosti ZVO v Ukraini na pochatok 2010/11-2019/20 navchalnykh rokiv: stat. informatsiia [The main indicators of free economic activity in Ukraine at the beginning of 2010/11-2019/20 academic years: stat. information]. Kyiv: Derzhstat Ukrainy. Available at: http:// www.ukrstat.gov.ua.

14. Stratehiia rozvytku vyshchoi osvity Ukrainy na 2021-2031 [Strategy for the development of higher education in Ukraine for 2021-2031]. Available at: https://mon.gov.ua/storage/app/media/rizne/2020/09/25/rozvitku-vishchoi-osviti-vukraini-02-10-2020.pdf.

15. Shkarlet S. Vyshcha osvita $v$ Ukraini. [Higher education in Ukraine]. Available at: https:// osvita.ua/vnz/80198/.

Стаття надійшла до редакції 11.03.2021. 